\title{
THE PRESIDENT AS INTERNATIONAL LEADER
}

\section{RichaRd P. LONGAKER*}

Before taking office in I9I3, Woodrow Wilson remarked to a friend: "It would be the irony of fate if my administration had to deal chiefly with foreign affairs." 1 Today, a President comes to office assured that he will spend most of his time and make his most difficult decisions in the field of global politics. Wilson's hopes were shattered by the First World War; Roosevelt's similar hopes by the Second; and within the last ten years, international leadership-a function that was thought to be temporary-has become a firm institutional addition to the American Presidency. Any President taking office today knows that one of his major responsibilities will be to attempt to exert leadership abroad, if not actually to lead. The emergence of this presidential function in recent years has added to the already distended powers of the chief executive, has changed in important respects the nature of the office, and has complicated the already complex problems of the Presidency. That this is true is demonstrated by the fact that the major constitutional struggles since the Second World War-the Bricker amendment, the Steel seizure, the Great Debate over presidential dispatch of troops to Europe, the McCarthy episode, and the intervention in the Korean War-were provoked by presidential responses to the demands of the new role. The purpose here is to identify the conditions under which the President can most successfully function as an international leader, to sketch briefly the historical development, to analyze the constitutional and institutional setting of his leadership, and to discuss some of the effects his new responsibility has on his traditional functions as a domestic leader.

The phrases used to describe the President's new role are various and frequently misleading. Some speak of the President as world leader, or as exercising world leadership. The existence of the Soviet Union, of course, precludes the use of this term, if taken literally. Others depict him as "leader of a coalition of free nations" or of a "coalition of the free,"' a title which is closer to the truth but overlooks the conflicting pressures of coalition leadership, the persuasion of neutrals, and the fact that the President tries to lead those, like Tito and Franco, who are not, ideologically speaking, free. The only term reasonably free from ambiguity is international leader, and even this phrase requires severe qualification, for the President's offer of leadership is often rejected. But still, the phrase implies at least an attempt by the President to work in concert with other nations in order to defend the national

* A.B. 1950, Swarthmore College; M.A. I95I, University of Wisconsin; Ph.D. 1954, Cornell University. Associate Professor of Political Science, Kenyon College.

${ }^{1}$ Wilson to E. G. Conklin, in 4 Ray S. Baker, Woodrow Wilson: Life aNd LetTers 55 (I93I).

2 Sec, for example, 2 Harky S. Truman, Memoirs 232 (1956); Robert J. Donovan, Eisenhower: The Inside Story 352 (1956); Nitze, The Modern President as a World Figure, 307 Axnals I14, I15 (1956); and Clinton L. Rossiter, The American Presidency 28 (1956). 
interest. It implies, moreover, that he becomes, on occasion, a vital influence in the policy making of other governments. The President can no longer stay at home; instead, he must journey beyond the boundaries of the United States in an effort to tip the balance of world power in favor of the United States. To assert that the President can no longer be passive director of American foreign relations is only to raise the question of how and when his leadership should be exercised. It is also to ask whether or not the President can, as the leader of a democratic nation in a constantly shifting international setting, exert leadership in a sustained fashion.

One President has stated that the essence of presidential leadership is to "persuade [people] to do what they ought to do without persuasion." 3 In the international field, the essence of leadership is to persuade other leaders that the self-interest of all dictates a common course of action. Persuasion is facilitated if the group is held together by common beliefs and common dangers and if the President can articulate, forcibly and clearly, mutual hopes and fears. Presidential leadership abroad, in other words, depends on the world situation, his own ability, and the political and economic circumstances in the United States. As contemporary restlessness in Europe indicates, both in Western Europe's renewed interest in a European union and the Anglo-French attack on Egypt, the President is inevitably involved in foreign affairs and must attempt to lead, but he is not inevitably an international leader. Like presidential leadership in Congress, presidential international leadership is potential and conditional. Too frequently it is suggested that the need inevitably produces the result.

\section{The Foundations of Effective International Leadership}

What then produces the potential and what factors must be present to transform the potential into effective leadership? Obviously, the major factor in the President's potential for leadership is the enormous strength of the United States, the productive skill of her people, her size, resources, and population. But other conditions are almost as essential.

Among the most important is the existence of a common threat and fear of the consequences of acting alone or-and this is much less cohesive-the existence of a common, positive policy that is based not on an external threat, but on common ideals and purposes. Fear of Soviet domination has led to the provisional acceptance of American leadership in the past and, as fear has dwindled, American leadership has dwindled with it. Another condition, closely related to the first, is that basic agreement on goals and strategy must be possible. Under present conditions, the common goal, to prevent the extension of Soviet influence, is provided, but there must also be the possibility of agreement on methods. Once again, when the possibility does not exist-as in the recent Anglo-French and American differences over policy in the Middle East, or British-American differences over Formosan policythe conditions for effective leadership are undermined. The same may be said for

\footnotetext{
${ }^{3}$ Rossiter, op. cit. stipra note 2, at 122.
} 
the political situation within the United States. If the President is to lead abroad, there must be common agreement among the important sectors of American society on the goals of his leadership and the methods to be used; in turn, his capacity for leadership is increased if there is a clear and tangible foreign threat to the nation's security. American leadership after 1945 was possible only because of the Vandenberg point of view; conversely, if there is any justification for Franklin D. Roosevelt's wavering before 1940 , it is his awareness of the deep division within the United States over the question of American involvement abroad. Leadership, to be effective, requires the possibility of reaching fundamental agreement among those to be led.

Ideally, international leadership also assumes the balanced use, under unified presidential direction, of industrial resources and skills, sound administrative techniques, military power, and an idea. In our recent history, the Marshall Plan and NATO illustrate the balanced application of the four essentials. Industrial resources and skill produce international reliance, if not dependence, upon the nation possessing them and upon the President who directs their export. Although there are exceptions, it is generally true that the curve of presidential leadership is tied to the curve of American economic and military assistance. It is possible, in other words, to purchase the right to lead, although the purchase is seldom directly over the counter. But economic persuasion must be supplemented by proper administrative techniques at home and abroad to allow for sound planning and unobtrusive execution of the President's leadership. Conflicting policy statements, such as the contrary views of President Eisenhower and his Secretary of State concerning the moral posture of "neutrals," can upset in a day prestige constructed over a period of months.

The willingness to use military force-or at least the determination not to renounce outright the use of force-is an essential condition of leadership. It is arguable that the excessively peaceful atmosphere at the "summit meetings" in Geneva and American guarantees that force would not be used during the recent Suez crisis were instrumental in cutting into the substance of presidential leadership. On the other hand, unwarranted truculence and overemphasis on military means can be as damaging as a faint military heart. The Berlin airlift and the use of the Seventh Fleet in the Formosa Straits are the best recent examples of the judicious use of military and industrial potential while avoiding, at the same time, the excesses of a shooting war. In order to maintain leadership, the President must follow the dictum of Theodore Roosevelt concerning soft speaking and the big stick, which, despite constant repetition, cannot be improved upon. Unobtrusively, but none the less clearly, the President must base his leadership on a firm military foundation. This raises the question of the adequacy of nuclear strategy as a support for presidential leadership. Does overdependence on the nuclear counterblow reduce the flexibility of the President's international leadership? The President's leadership, if it is to be sustained and effective, must be based on a tactical air arm and mobile naval force, as well as powerful ground forces. If the President bases his 
leadership solidly on the ultimate weapon, he is likely to be frozen in a position of inaction as lesser wars swirl about him and lose initiative to allies who expect small fires to be quenched by carefully controlled methods, not a deluge. The police action and the use of "volunteers," not nuclear war, have become the standard for military involvement in recent years and if the President is to maintain initiative, there cannot be sole reliance on nuclear strategy. As the American intervention in Korea, among other crises, proves, the path of leadership follows a swath cut by infantrymen as well as the threat of ultimate nuclear war. The President has the unenviable task of finding a balance between the two.

Military might, industrial strength, and administrative techniques must be tied to an idea, both to activate those who are implementing policy and to assist in the persuasion of those who are willing to follow presidential leadership. Wilson's Fourteen Points, the Four Freedoms, the defensive Atlantic alliance, Point Four, and Atoms for Peace are all ideas which aroused attention and hope, have helped to persuade, and have symbolized presidential initiative and firm intentions. The idea must be transcendent and mix national interest and humanitarianism in an attractive blend. It must possess the elasticity which admits Titoists, Falangists, and Syngman Rhee and yet avoid the imputation of opportunism. The proposal to admit Eastern European nations into the Marshall Plan-so quickly rejected by the Soviet Union -allowed this program to meet this difficult test.

Successful presidential leadership, besides requiring harmony of military, administrative, industrial, and ideological effort, requires the adroit use of propaganda weapons to articulate the presidential effort. His leadership can fail if the goals are not made known or if they are not understood, enlivened, and protected against counterattack. The long struggle to reactivate the propaganda services, which were temporarily abandoned in 1945, reached a turning point in the first month of the Eisenhower administration with the establishment of the United States Information Service and the appointment of a special assistant to the President on propaganda matters. ${ }^{4}$ Unfortunately for presidential efficiency in this field, the chief executive of a democratic state can never be the single voice heard overseas. Much of the propaganda effort cannot be positive presentation of principles and presidential programs, but must be directed toward counteracting the exploitable weaknesses-as in the field of civil rights or outbursts of McCarthyism-in the United States. Even though a democratic society compounds the difficulties, this does not obviate the necessity for the effective use of propaganda techniques as an active support for international leadership.

Finally, in the domestic sphere, sound international leadership by the President presupposes a substantial degree of institutional harmony between the President and both parties in Congress as well as presidential willingness to sacrifice shortterm political advantage in the interests of consistent leadership abroad. Many

\footnotetext{
${ }^{4}$ Sargeant, Information and Cultural Representation Overseas, in THE RePresentation of tuE United States Abroad it (I956).
} 
instances can be cited of a breakdown in congressional-executive relations which have temporarily disabled the President's leadership overseas-the League fight in the Senate in IgIg, the isolationist power in Congress in 1940-4I, the Taft-Wherry resistance to the dispatch of American troops in support of NATO, the right wing Republican attack on American foreign policy in the Far East, and, more recently, the strong congressional protests against foreign aid appropriations. Congressional criticism of the President, when not blatantly partisan, is helpful, and fortunately there are many examples of cooperation, particularly under the guidance of Senators Vandenberg and George. In Congress, the President must satisfy the demands of what one commentator calls "extra-partisanship," the ambidextrous posture of using his party but not as a partisan, working "outside party lines while maintaining a base of support in [his] party." Effective leadership abroad must first meet the test of effective leadership within the United States, in the parties, in Congress, and among the public at large.

What has been said about the necessary conditions for effective international leadership by the President is, of course, the counsel of perfection. Because the conditions are affected by the global balance or imbalance, by the necessities of popular government, including the separation of powers, and by the intangible quality of many of the problems to be solved, it is patently impossible for a President to meet all of the requirements fully. But since he is constitutionally responsible for defending the national interest, he is, nevertheless, obliged to make the attempt.

The Historical Development of the President's Role as International Leader

Every President since Washington has been committed to the defense of America's national interest, although from Washington's time until recent years, Presidents performed their duty by withdrawing from permanent international involvement and active intervention as international leaders. The policies in Latin America during the first one hundred and thirty years of United States history provided a severely limited dress rehearsal for later international leadership by the President. From the Monroe Doctrine through the Venezuela crisis and the Roosevelt corollary to the seizing of Panama, there was no lack of recognition of American interest to the south, even though the methods fell far short of the modern tests of constructive leadership. The subsequent Good Neighbor policy and the cooperative efforts culminating in the Rio Pact in 1947, mark the emergence of American leadership based on factors other than force and dollar diplomacy. In the Spanish-American War, the United States came of age as an international military power if only, among the many tangled motives, to continue a pattern of American hegemony in the Western Hemisphere. If there is similarity between the Presidents' experience in Latin America and the broad international commitments of today, it lies in the fact that American policy in most instances-the Monroe Doctrine, the Roosevelt corollary, Caribbean intervention, and even the more recent Guatemala intervention-was a

- Bradford Westerfield, Foreign Policy and Party Politics i6 (ig55). 
reaction against outside pressure and not a product of positive presidential initiative. The Presidents' involvement in the Western Hemisphere differed from today's international leadership not only in the restricted geographical commitment, but in the methods and spirit underlying that leadership. The policies, except for the Spanish-American War, were basically unilateral executive actions with limited congressional participation, the part played by the Government was largely diplomatic and military, not economic, and the settlements were imposed unilaterally by the United States from a position of uncompromising strength.

Not until after the Second World War did the President assume the full obligation of international leadership in situations where the force or the threat of force is inadequate in itself, where Congress is a continually active partner, and where there is a complete industrial commitment and association with permanent alliances. The first President, in other words, to accept international leadership as a full-time job was President Truman, although his predecessors haltingly prepared the way. The only President to have positive enthusiasm for the role was Theodore Roosevelt; all others were drawn into leadership initially because of the failure of leadership elsewhere and in reaction to external pressure. Only Theodore Roosevelt attempted international leadership, in the first instance, because of his own sense of enterprise.

Most Presidents, seemingly, have been reluctant to try to lead abroad because they have realized from the beginning-as Wilson did too late-the limitations which the constitutional system and America's fundamental noninterventionism would impose on their leadership. And many have shared with their compatriots an aversion to "foreign" entanglements. Wilson moved hesitatingly, and only after agonizing reflection, to shatter the stalemate of the First World War and to secure the balance of power in the moral world he envisioned. ${ }^{6}$ FDR was less hesitant but reaped Wilson's whirlwind and struggled against this before participating in the destruction of governments whose hostility to the United States had long been known. And Harry Truman moved to check anti-Communist forces in Greece and Turkey and Europe only in the face of British withdrawal and near chaos in Europe. American leadership, since Theodore Roosevelt, has been, in short, the leadership of counterattack. The first Roosevelt understood the demands of leadership as well as any President but although he had the script-except for Algeciras and Portsmouth-he did not have the world stage. There was no need for the President to direct the forces of stability when the world was already stable.

The history of presidential leadership from Wilson to Truman can be describedto borrow a phrase from an authority on diplomacy-as a shift in emphasis from the search for justice to the search for security. Woodrow Wilson, the first President to become actively engaged on the entire world stage, did not fully appreciate

- See i Charles Semmour, The Intmacate Papers of Colonel House 296-98 (1926); and 2 id. at at 228.

${ }^{2}$ Buchrig, Idealism and Statecraft, 5 Confluence 252 (1956). 
either. The principal characteristic of Wilson's leadership abroad was its excessively sanguine and moral quality. He recognized as early as 1900 that the "plunge into international politics" in the war with Spain had "greatly increased [the President's] power and opportunity for constructive statesmanship...." Until I9I7, however, he was extremely reluctant to intervene outside the Western Hemisphere, although his later attitude was foreshadowed by his moral crusade in Mexico. He assumed a commanding role in the First World War only at the last moment, but with the Fourteen Points, the negotiations in Paris, and during the League fight, he accepted the presidential obligation of international leadership with a vengeance. His failure or the failure of his less optimistic compatriots brought about a reaction against presidential involvement abroad which only Pearl Harbor and the fear of Soviet absorption of Europe after 1945 could dispel.

It is significant that American efforts in leadership in the interwar period are associated with the names of Secretaries of State: Hughes with the Washington Conference, Stimson with Manchuria, Hull with the London Economic Conference and the more successful Reciprocal Trade Program. Presidents did not seem to sense the obligation, and if they did, public opinion and not the President, set the tone. One need only cite FDR's attitude toward the London Economic Conference, his failure to offset the Nye investigations by a public statement warning of the fatal weakness of its conclusions, ${ }^{9}$ or his support of the Neutrality Act in the campaign of $194^{10}$ to realize both public and presidential abdication of international responsibility. Only the timid foray of the "quarantine" speech, the quiet preparation for war by the joint Anglo-American staff after January i94x, and the Curtiss-Wright decision stand out as reminders that the President possessed the potential to lead.

The Lend-Lease Act, combining as it did the essentials of industrial power, administrative techniques, cautious military support, and an idea, marks the breakthrough. The President's international leadership under Roosevelt was characterized by its personal quality, as Churchill's leadership was. There is little doubt that FDR was the dominant leader-if only by Churchill's conscious submission to the fact of American industrial and military superiority. Because of Roosevelt's administrative methods and his shortsighted evaluation of postwar conditions, presidential leadership was not institutionalized; however, the combination of Truman's administrative methods, the National Security Act of 1947, the Marshall Plan, and NATO, finally brought about the institutionalization of the President's new role. The British retreat from international leadership and the realities of a bipolar world made clear that the President's responsibility was neither temporary nor could it afford to be merely personal. The easy adaptability of Roosevelt's leadership was gradually exchanged for the sometimes excessively institutionalized

\footnotetext{
8 Woodrow Wilson, Congressional Government 22 (Meridian Books, 1956).

- James MacGregor Burns, Roosevelt: The Lion and the Fox 254 (1956).

${ }^{10}$ Robert E. Sherwood, Roosevelt and Hopkins 189 (1948).
} 
and security-conscious presidential leadership of today. Recent and past experience suggests that contemporary international leadership cannot depend alone on military security or moral leadership. Neither will it succeed if it is merely personal or rigidly institutional. It requires the difficult mixture of sound institutional support, of personal leadership, and the balanced application of justice and security.

\section{The Constitutional Basis}

The constitutional basis for the President's role as leader is no more than an extension and broadening of his traditional responsibilities as chief of foreign relations. There is no better description of this function than in Durand v. Hollins: ${ }^{11}$

As the Executive head of the nation, the President is made the only legitimate organ of the General Government, to open and carry on correspondence or negotiations with foreign nations, in matters concerning the interests of the country or of its citizens. It is to him, also, that citizens abroad must look for protection of person and property, and for the faithful execution of the laws existing and intended for their protection. For this purpose, the whole executive power of the country is placed in his hands, under the Constitution, and the laws passed in pursuance thereof. ... The great object and duty of Government is the protection of the lives, liberty, and property of the people composing it, whether abroad or at home; and any Government failing in the accomplishment of the object, or the performance of the duty, is not worth preserving.

In the first instance, the President's power to assume the responsibilities of international leader arises from his constitutional status as the executive head of the nation. As Hamilton pointed out in the Pacificus-Helvidius exchange with Madison, the President is not merely the instrument of Congress in foreign relations, but the possessor of independent executive power of which the specifically mentioned subsidiary powers to appoint ambassadors and to make treaties are minor manifestations. $^{12}$ The notion was reaffirmed in the Hoover Commission Task Force Report on Foreign Affairs: ${ }^{13}$

The Constitution has left a great area of unassigned powers in which someone must act for the United States from time to time, and in the absence of any other assignment, the President, in his capacity as executive, is the only one able to act.

Possession of independent executive power means that the President cannot be satisfied in following a course set by the legislature in foreign affairs, but must search actively for the path leading to national advancement and preservation. In turn, he is not limited to action approved by Congress, but can employ any means not prohibited by the Constitution or the laws "to safeguard the nation."14 The consti-

118 Fed. Cas. No. 4186, at II2 (C. C. S. D. N. Y. I860). See Edward S. Corwin, The President c. 5 (1948).

${ }^{13} 4$ The Works of Alexander Hamilton 438-40 (Lodge ed. i885).

${ }^{13}$ Commission on Organization of the Executive Branch, Task Force Report on Foreion AfFaIRs 47 (1949).

14 This theory is associated with Theodore Roosevelt but has been adopted by most strong Presidents. 2 Truman, op. cit. supra note 2 , at 473,478 (1956). 
tutional reasoning that vests positive executive power in the President and thus bestows on him the responsibility for all positive action not prohibited by the Constitution or statutes, including leadership abroad, rests on a practical foundation that was clearly described by John Jay in Federalist 64-namely, that the President, as distinguished from Congress, can bring to bear on foreign affairs secrecy, dispatch, and unity. The unity of the executive-the single voice and hand of leadershipthe necessity for secrecy, a center of information and coordination of policy, and dispatch in implementing policy and protecting the nation in times of crisis have all received the sanction of custom. This has been demonstrated in recognition policy, in the right of the President to withhold documents from Congress, in statutes (generous delegations of power by Congress in foreign affairs), and in judicial decisions (from Martin v. Mott ${ }^{15}$ to United States v. Curtiss-Wright Export Corp. ${ }^{16}$ ) over the years.

The broad interpretation of the opening words of Article II vesting the executive power in the President, buttressed by the practical arguments for presidential direction of foreign affairs, does not provide the only constitutional permission for presidential involvement in leadership abroad. He is also supported by the specific grants of power to see to the faithful execution of the laws and his function as commander-in-chief. The presidential obligation faithfully to execute the laws is a formidable grant of power in an era of extensive treaty-making; whether action is taken under Article V of the North Atlantic treaty, the United Nations treaty and the UN Participation Act, or lesser agreements, the President is as likely to move into a position of international leadership in executing the treaties as he was while negotiating them. President Truman based American entry into one of the nation's most frustrating but perhaps most fruitful wars, the "police" action in Korea, on his obligation to accomplish the faithful execution of the laws-in this case, the UN Charter. Because of American military and economic power, the President, in this instance, and potentially under the NATO system, has become the executive representative of the signatory nations in enforcing international law.

Moreover, it is a settled principle of constitutional law that the President's power as commander-in-chief is a broad discretionary grant permitting the President to deploy the armed forces in peacetime as well as war, for his own chosen diplomatic or strategic purposes. The Eisenhower administration has imposed limitations on itself in this regard by declaring that any movement of troops that might involve the United States in war should follow a congressional resolution bestowing discretion on the President. This procedure was followed in the Formosa crisis, for Quemoy and Matsu in the Pescadores, but it is more a product of domestic political tactics than constitutional law. And President Eisenhower and his Secretary of State have specifically reserved the plenary power of the President on occasions when Congress cannot be consulted and have denied that Congress must be consulted to

$15_{25}$ U. S. (12 Wheat.) 19 (1827).

${ }^{10} 299$ U. S. 304 (1936). 
determine the disposition of forces when there is no proximity to actual conflict. ${ }^{17}$ President Truman relied, in part, on his power as commander-in-chief-independent of prior congressional approval-to send United States troops into Korea. The role of the commander-in-chief in peacetime was exhaustively considered during the Great Debate in Congress in 195I over presidential assignment of troops to Europe without express congressional approval and was finally settled to presidential advantage. At that time, the President and his advisers contended that his power to dispatch troops was plenary, and the extent to which the commander-in-chief clause contributes to the President's function as leader, in peacetime, is clear in the following statement, one of many similar declarations to appear during the Great Debate: ${ }^{18}$

In time of peace the President is just as much Commander in Chief as he is in time of war. His power over the Armed Forces remains the same. But in time of peace the exercise of that power is directed, not at subduing an enemy, but at broader considerations of national policy in general. In particular, the peacetime functions of the Commander in Chief are related to our defense needs and to the responsibilities of the President in the field of foreign affairs.

Finally, some Presidents have contended that the constitutional foundations for leadership abroad are supplemented, indirectly, by the President's oath of office. As Robert Sherwood states in Roosevelt and Hopkins: "Having taken the oath of office as President three times, he knew it by heart, and was well aware that he was sworn not only to "uphold" but to "defend" the Constitution of the United States. It was a matter of his own judgment-and the judgment of his advisers whom he was empowered to appoint-as to where that defense should begin." ${ }^{10}$ The oath to defend the Constitution is, in effect, the oath to defend the sovereign integrity of the United States. It can be-if only indirectly-an additional support for presidential initiative in bringing other nations together in defense of mutual global interests.

Besides the constitutional basis for presidential leadership in foreign affairs, the President gains authority from statutory grants of power. His authority is also reinforced by treaties, by executive agreements, by establishing or giving the President power to establish agencies to assist him in his foreign responsibilities, and by appropriations. And it was settled in the Curtiss-Wright case that statutory gifts of discretion in foreign affairs are not to be judged by the ordinary interpretation of delegated powers. Affirming "the very delicate, plenary and exclusive power of the President as the sole organ of the federal government in the field of international

\footnotetext{
${ }^{17}$ Statement by Secretary of State Dulles at the Nine Power Conference on Western Defense, Sept. 29, 1954, 31 Dep't STATE Bull. 523 (1924); Message to Congress on the Formosan Situation, Jan. 24, 1955, Security of the United States of America, H. Doc. No. 76, 84th Cong., Ist Sess. (1955), 32 DeP'T State Bulz. 21 I (1955); and presidential press conference, Dec. 2, 1954, N. Y. Times, Dec. 3, 1954, p. 18, cols. 2-7.

${ }_{10}$ Committee on Foreign Relations and Committee on the Armed Services, Powers of the President to Send the Armed Forces Outside the United States, 82d Cong., Ist Sess. 5 (1951).

${ }^{10}$ SHERwOOD, Op. cit. supra note 10, at 274 .
} 
relations," Justice Sutherland went on to declare that it was unwise for Congress to stipulate narrow and definite standards in delegating power to the President: ${ }^{20}$

It is quite apparent that if, in the maintenance of our international relations, embarrassment-perhaps serious embarrassment-is to be avoided and success for our aims achieved, congressional legislation which is to be made effective, through negotiation and inquiry within the international field must often accord to the President a degree of discretion and freedom from statutory restriction which would not be admissible were domestic affairs alone involved.

\section{The Institutionad Background}

Today, the most impressive characteristic of presidential leadership in the international field is the high degree of institutionalization. In contrast with the situation before the First World War, when our international commitments were hardly greater than the Pan American Union and the International Postal Union, and when Wilson depended on Colonel House and the Department of State, the President today is indirect or direct participant in at least five treaty organizations (ANZUS, SEATO, NATO, the Rio Pact, UN) and numerous specialized international organizations and eight domestic agencies devoted solely to assisting him in his international duties and numberless others that assist him indirectly. The complicated structure that stands behind the President's international leadership has increased in size, if not in efficiency, with the growth of presidential responsibility abroad, and nearly all agencies have come to participate actively in support of the President's leadership. That the Department of State and the military departments have become only partial contributors to the making and execution of foreign policy is as much of a truism as the statement that all aspects of domestic affairs in the United States have a direct or indirect effect on America's global position. In recent years, for example, the Departments of Agriculture, State, and Treasury have been, on occasion, intimately involved with questions influencing the President's position overseas; Agriculture in the proper use of farm surpluses and technical aid; the Treasury-as the active life of Secretary Humphrey indicates-in the task of finding a balance between domestic economic health and commitments abroad; and Justice in the production of legal opinions-such as the "destroyers for bases" contribution of Attorney General Jackson.

Hand in hand with the deeper involvement of the traditional departments in providing assistance to the President in his new role, efforts have been made to adjust institutions in the more immediate presidential family to the urgent demands for advice and the coordination of policy making and execution. Though some of these agencies, such as the Council of Economic Advisers and the Bureau of the Budget, were established by Congress to deal predominantly with domestic problems, they have necessarily felt the weight of the President's international obligation. Others were designed specifically to help the President shoulder this weight. The Atomic Energy Commission, the Central Intelligence Agency, the Joint Chiefs of Staff, the

${ }^{20} 299$ U. S. at 320 . 
Office of Defense Mobilization, and the National Security Council with its helpmeet, the Operations Coordinating Board, have appeared and developed since 1947, the year when the President learned that leadership abroad was to be more than a temporary responsibility. Other offices, commissions, and ad hoc individual assignments, such as Harold Stassen's job as Secretary of Peace, or Disarmament, Clarence Randall's Commission on Foreign Trade and his more recent appointment as Special Adviser to the President on Foreign Economic Affairs, and the Office of the Special Assistant to the President in National Security Affairs appear and dissolve depending on the degree of presidential need and favor. No more compelling evidence is required of the existence of the President's new responsibility or the personal and institutional burden it places on him than the increase in the number of individuals reporting to him in this field.

How these agencies are used or if they are used at all depends, in the first instance, on international conditions and the administrative preference of the President and his immediate staff. There is no best way to arrange institutional support for presidential international leadership without considering the person in office or the problem at hand. There are principles of coordination of the international effort, the establishment of clear lines of responsibility and action, and the requirement that adequate information gets to the President; but each President has tended in the past, and doubtless will tend in the future, to shape the institutions to fit his workaday world.

Woodrow Wilson delegated much authority in foreign affairs to Secretary of State Bryan until the situation in Mexico and the threat of American involvement in Europe produced a change. Cordell Hull, among others, has given adequate testimony of FDR's frequent by-passing of the State Department in his exercise of leadership, ${ }^{21}$ substituting Harry Hopkins, personal contact with foreign executives, and the Naval communications system for the traditional State Department channels. The National Security Council, under Truman, according to one set of authorities, tended to become "a sifter of staff memoranda,"22 and the most momentous decision of the Truman Administration, the intervention in Korea, was made without consultation with the Council meeting as such, although weekly meetings were made routine after that decision. ${ }^{23}$ President Eisenhower, with his reliance on an almost air-tight staff system, has elevated and formalized the advisory role of the Council. Although he overruled the Council on the question of American intervention in Indo-China, consultation preceded the decision, and it is permissible to guess that he relies heavily on Council staff work and on the discussion and final opinions of the participants. He maintains, as Truman did not, a Special Assistant on National Security Affairs who directs the work of the Council, and has established the Operations Coordinating Board to try to insure the execution

212 The Memoirs of Cordell Hull y rog-ix (1948); Burns, op. cit. supra note 9, at 383 .

22 William Y. Elliott, United States Foreign Policy: Its Organization and Contror 71 (1952).

${ }^{23}$ Truman, op. cit. supra note 2, at 59-60, 333, 334 (1956). 
of decisions made by the Council. There is no assurance, however, that Eisenhower's changes or his reliance on the Council will set the pattern for his successor.

These aids to the President, in other words, have no life of their own, but live in prosperity or poverty depending on the working habits of the President or the situation at hand. Much the same can be said for the utilization of international agencies, although here international conditions and the nature of the issue are as important as personal preference in conditioning presidential choice. The United States, perhaps more than any other nation, has depended on the United Nations for its institutional leadership abroad. The original Baruch Plan, the United Action for Peace Plan, intervention in Korea, the recent resolutions condemning the AngloFrench involvement in Egypt, and the Atoms for Peace program were all initiated by American Presidents in the international agency. Presidential dependence on the United Nations has been based on the voting support in the General Assemblyas the United Action for Peace Plan illustrates-of the generally sympathetic South American and Western European blocs. With the addition of sixteen new states by the Eleventh General Assembly, a reliable majority may not henceforth be available, and, thus, presidential use of the United Nations may become less frequent, demonstrating again that the institutional expression of presidential leadership abroad is relative to the international circumstances. Two examples will perhaps emphasize the point. Notwithstanding President Truman's reliance on the United Nations, it is clear that United States forces would have been committed to Korea even without United Nations support. Only the fortuitous absence of the Soviet Union from the Security Council permitted the President to add the prestige of the United Nations to the prestige of the United States in this crisis. Secondly, the importance of NATO has declined as a vehicle of presidential leadership as disagreements within the Western alliance have increased in frequency and intensity. There can be, in sum, no set institutional pattern for the application of international leadership in Washington or overseas. This factor puts additional strain on presidential decisiveness and imagination.

\section{The Impact of International Leadership on the Presidency}

What have been the consequences of the President's attempts to fill his new role, and what problems are created for the presidential office? The changes in the Presidency within the last ten years, largely because of the new responsibility, have been as great as the change in the preceding fifty years. It can be said that in most respects Franklin Roosevelt's first term and the years of the Hoover administration bear a greater resemblance to the Presidency of Grover Cleveland than to that of Harry Truman. Just as America's involvement in world affairs has affected the entire governmental system, the President's new responsibility has had a strong impact on the traditional functions of the President and intensified old problems. It is not as if one more function had been added to total one more than the previous number of duties; rather, all of the traditional duties have been immersed in and 
distorted by the overriding function of international leadership. To illustrate how complete the invasion of his other responsibilities has been, it is only necessary to mark the relatively new presidential obligations of maintaining national prosperity and promoting civil liberties. The interrelationship between the President's international responsibility and his national obligations is apparent. The one complicates and intensifies the other. If the President avoids acting in the interest of civil liberties by not enforcing the law or does not stand as a defender of civil rights and legislative leader of reform in that field or if he does not take an active role in promoting economic health at home, his leadership abroad suffers through the loss of national prestige and power. In fact, it can be asserted that the President's role as international leader has been instrumental in the firm establishment of these other two twentieth-century additions to the President's duties. ${ }^{24}$ A sick economy or a vacillating policy in civil rights can be as damaging to the President's efforts to lead abroad as the lack of adequate military power. In sum, none of his duties are free from international consequences.

This is apparent as one observes the impact of international leadership on the traditional presidential functions. The addition of a fluctuating international constituency to the President's national constituency has strengthened Congress, has heaped new administrative problems on an already overburdened office and has stultified the theory of less strenuous years that the President is to follow and represent public opinion rather than lead or oppose, even in the field of foreign affairs, where popular self-interest is not always enlightened and apathy, misinformation, and prejudice frequently hold sway. ${ }^{25} \mathrm{~A}$ new and complicating ingredient has been added to presidential decision-making, an ingredient which has had a considerable, and a still unmeasurable impact, on the tactics of leadership at home and the institutions through which the leadership must be exercised. The executive, in the period since 1945, has been confronted with a decisive gain in the power of Congress, a gain which is, paradoxically, largely the result of increased presidential power and responsibility. Even in delegated legislative power, particularly in foreign affairs and beginning significantly with the Lend-Lease Act, Congress is making more and more use of joint or concurrent resolutions to provide for the withdrawal, at short notice, of power granted to the President. ${ }^{20}$ The major reason for the increase in congressional power is the monetary necessities of leadership and consequent executive dependence on congressional appropriations. The power of the Senate over treaties is now shared with the entire Congress, since the implementation of treaties depends on appropriations. This reinvigoration of congressional power in the cold war manifests itself in numberless investigations by congressional committees, concessions made by the President to Congress on appointments, and-a development of better promise-the active participation of congressional leaders of

${ }^{24}$ President's Commitiee on Civil Rights, To Secure These Rights, I46-48 (1948).

25 Walter Lippanann, Essays in the Public Pailosophy cc. I-2 (1955).

${ }^{26}$ Ginnane, The Control of Federal Administration by Congressional Resolutions and Committees, 66 HARV. L. Rev. 569 (1953). 
both parties in executive foreign policy councils. The reinvigorated power of Congress calls for subdued use of the old weapons of legislative leadership and a new emphasis on collaboration and conciliation in achieving crucial foreign-policy goals. In his role as legislative leader, the President must be more cautious than formerly and depend on his position as the best informed observer on foreign affairs in the United States to carry the day in Congress. His most effective weapon today is an appeal to Congress on the basis of national security and survival. He may appeal indirectly to Congress through the electorate or to the consciences of individual Congressmen. But this appeal must be used sparingly. Ultimately, he can by-pass the Congress, as President Roosevelt did in $1942 ;^{27}$ but when there is no hot war, this road can lead directly to a legislative dead end. Unless the President wishes to take this chance, he can no longer be cavalier in his legislative leadership. And, if changed tactics are one of the results of the President's international role, it should be added that the President is forced, at times, to give less emphasis than he otherwise would to domestic legislation. In some cases, the quid pro quo of international leadership does mean the partial dissolution of leadership in the domestic field and the delegation of this traditional responsibility to others, either in or out of the presidential household. ${ }^{28}$

Recent Presidents have recognized the increased power of Congress by supporting greater collaboration between congressional committees and the executive agencies and closer contact between the President and congressional leaders at a higher level. What once was desirable is now essential. His relationship to his party and interest groups has also been affected by his new international role. Directly, and through Congress and his party, the President feels the pressure of group demands and particularism which frequently run counter to the interests of sound international leadership. Important contributors to his party, loyal followers, and important groups in pivotal states lay claim to presidential allegiance. Members of Congress, party leaders, and pressure groups-whether they are bicycle manufacturers interested in special tariff consideration, farmers demanding quotas or destructive dumping, Zionists, Irish-Americans, Slavic-Americans, or others sharing common loyalties with groups or nations abroad-complicate and can obstruct, by the very nature of their particularistic point of view, the President's efforts toward sound international leadership. He must make the choice, and if it is against the group interest, more often than not it will be a politically unpleasant one. In years past, the President faced the relatively less difficult task of balancing the interests of this national constituency against sectional or economic particularism; today, he must include his international constituency in the equation. The Democratic Party's policy toward Israel and the Republican commitment to "liberation" indicate that

\footnotetext{
${ }^{37}$ Message to Congress, Sept. 7, I942, Domestic Economy of the United States, H. Doc. 834, 77th Cong., 2d Sess. (1942), 88 Conc. Rec. 7052 (1942).

${ }^{28}$ Referring to a dispute between two department heads, Sherman Adams is said to have remarked: "Either make up your mind or else tell me and I will do it. We cannot bother the President with this. He is trying to keep the world from war." Donovan, op. cit. supra note 2, at 71 .
} 
partisan considerations can never be suppressed but as long as the cold war lasts, the President cannot return to the free wheeling party leadership of an earlier day without harming vital American interests and seriously jeopardizing his own success as international leader.

The administrative consequences of the President's assumption of the role of international leader are as striking as the effects on his traditional roles as party and legislative leader. The growth of the bureaucracy in recent years is largely a product of the President's need for help in fulfilling his new international responsibility. Help indeed has been given, but the very increase in size has tended to put the President in the center of a milling throng of unknown faces and has raised seemingly insuperable problems of coordination and implementation. Conflicting policies and statements are unavoidable even at the highest level, as the recent controversy over the state of American defenses indicates. When deeply felt professional and departmental loyalties are at stake, as they have been within the Department of State or in the controversies between State, Defense, and Agriculture, coordination and willing implementation are doubly difficult. Institutionalization of the President's role as international leader is a partial answer as the development of the staff system and more extensive use of the National Security Council and such agencies as the Operations Coordinating Board under President Eisenhower demonstrate. But institutionalization can never be the complete answer, partly because no amount of institutionalization can suppress the centrifugal forces within such a large institutional group, and partly because institutionalization itself can breed currents of inefficiency.

Some critics contend that inflexibility and lack of imagnation have been the fruits of excessive institutionalization under President Eisenhower's leadership. Whether this specific charge is valid or not, it seems quite certain that overdependence on the channels of the National Security Council, a staff system, along with limited access to a busy President, can create obstructions to creative thinking as well as remove them. There can be no substitute for the haphazard, sometimes accidental, gifts of information that can come to a President from unexpected places. Presidents Roosevelt and Truman depended on side-door informants whose ideas, had the doors not been opened, might have been smothered in institutional channels. President Eisenhower's informal dinners at the White House have also served this purpose, and all Presidents have benefited from the weekly press conference which should share honors with congressional visitors as a method for breaking down institutional barriers. Similarly, as the President's leadership can be distorted in institutional channels, his active leadership abroad can wane if it becomes impersonal. The President cannot speak continually through the Department of State or indirectly through his press secretary. By clever use of the press conference, appearances before international agencies, and occasional trips to the summit, the President can avoid being mired down in an administration designed to liberate him.

A final administrative problem that has been intensified by the President's 
responsibilities abroad is presidential control of specialists within his own administration-whether they are of the economic, scientific, or military variety. Lacking special knowledge in one or more of these fields, the President must be on guard constantly against the necessarily one-sided view of experts. From a military or scientific viewpoint, for example, the continued testing of the hydrogen bomb may seem sound, and yet, if the decision is made on technical grounds alone, the President's prestige abroad may suffer. President Eisenhower has avoided the dilemma of overdependence on expert advice in a technical world because of his own unique military and diplomatic experience. President Truman depended on many hours of study and an awareness that even a technical decision was his alone. As he describes his first day in office: $:^{29}$

... on that first full day as President I did more reading than I ever thought I could. I even selected some papers to take home so that I might study them before retiring and upon waking. This was the first step in a routine of nightly work that I found to be one of the most trying but also one of the necessary duties of a President.

Difficult as it may be to resist the apparent certainties of technical advice, expert opinion can never substitute for the reflective over-all view of the President. With his new responsibility, in an increasingly complex world, the President is forced to redouble his efforts to escape from the narrow, technical point of view. Living as he does in an administrative labyrinth lined with the opinions of experts and specialists, this requires administrative skill, some audacity, and perhaps super-human wisdom.

Finally, the President's international role has placed in a new perspective the relationship of the President to public opinion. Before the President had assumed the obligation to try to lead other nations, he could afford to follow public opinion and define the relationship with the public as one of translating electoral sentiment into governmental action. When international leadership was added, however, other factors came into play: the necessity for being aware of sentiment outside the United States and being the active guide of opinion, and, on occasion, to be willing to act against immediate popular wishes. The President's obligation to his national constituency is no longer one of reflecting sentiment, but forming it. He must articulate for the public in understandable terms the reason for presidential involvement abroad. He must be able to establish in the public mind the consequences of a failure to lead and make dramatically clear what Lippmann calls "the intangible realities" of international power. ${ }^{30}$

Under any circumstances, guiding public opinion is more difficult than transforming public wishes into legislation. The difficulty is compounded in foreign affairs because the issues, except in the pure air of an emergency, are not clear or easily clarified. They are obscured by distance and their own complexity, while the alternatives presented to the public are not between the pleasant and unpleasant

\footnotetext{
${ }^{29}$ I Truman, op. cit. supra note 2, at 26-27 (1956).

${ }^{30}$ LippMan, op. cit. supra note 25 , at 55 .
} 
but between the least unpleasant and the most unpleasant. The President must have a rich fund of popular support if his leadership is to be sustained, but at the same time he must be prepared to act without popular support if reflection and sound advice dictate action in the national interest. Popularity is no measure of sound public policy in this field. 'The crux of the President's relationship with the public in this new situation is, in fact, the long-term preparation of public opinion for the unpopular action by a careful mixture of exhortation and appeals to self preservation. The President can no longer permit the quality of his leadership to be molded by powerful interest groups; he can no longer be the passive receptacle of active public opinion, partly because in foreign affairs there is oftentimes no public opinion. He must create public opinion and yet refuse to yield to public voices which, if followed, would cast doubt on his capacity to lead abroad. The President must take full account of the palatable or unpalatable truth of America's international position and make that position forcefully clear in the public mind. As Thucydides remarked of Pericles, "Certainly when he saw that they were going too far in a mood of over-confidence, he would bring back to them a sense of their dangers; and when they were discouraged for no good reason he would restore their confidence." And he must be willing to accept the short-run political sacrifices that international leadership demands.

Since President Eisenhower's illness in 1955, it is impossible to discuss the Presidency without recognizing that the President's efforts to direct unpredictable international forces in the face of resourceful maneuvers by the Soviet Union, the contradictory interests of American allies and neutrals, and a complex constitutional system contribute more than any other activity to the tense weariness associated with the modern Presidency. If the Presidency is today, as Harry Truman described it, "like riding a tiger," it is because the President must deal with gargantuan imponderables which frequently cannot be reflected upon or completely understood but only inspected hurriedly before a decision is made. Perhaps history will conclude that the job is beyond the capacity of the man and the office, even though costly adjustments have been made to meet the President's new role. When one recalls the optimum conditions for effective international leadership-harmonious congressional-executive relations, effective administrative planning and coordination, the presence of a cohesive force abroad, among others-it is quite apparent that the President will never reach the exalted position of sustained international leadership, even if this were desirable, short of a severe world crisis or actual war. The present cold war environment requires that the President attempt to lead in the interest of American security, even though the attempt alone complicates his other presidential functions. He can only hope, when the anti-Soviet forces need leadership, that for an undetermined period of time his leadership will take hold. 